\title{
STANDARDISASI PRODUK KECAP KEDELAI MANIS SEBAGAI PRODUK KHAS INDONESIA
}

\section{Standardization of Soy Sauce Sweet Product as Product Specialty of Indonesia}

\author{
Yuliasri Ramadhani Meutia
}

\author{
Balai Besar Industri Agro \\ JI. Ir. H. Juanda No. 11 Bogor 16122, Jawa Barat, Indonesia \\ email: yhoely@yahoo.com
}

Diterima: 22 Mei 2015, Direvisi: 29 Juni 2015, Disetujui: 30 Juni 2015

\begin{abstract}
Abstrak
Kecap kedelai merupakan salah satu produk fermentasi yang telah dikenal sejak ribuan tahun yang lalu di berbagai negara termasuk Indonesia. Namun kecap kedelai manis merupakan produk kecap kedelai yang merupakan produk khas Indonesia. Tujuan penelitian ini adalah untuk mengembangkan standardisasi produk kecap kedelai untuk memperkenalkan dan meningkatkan citra produk ini. Pada kajian ini dilakukan perbandingan antara data hasil pengujian kecap kedelai manis dari beberapa produk yang beredar di Indonesia dengan beberapa literatur, serta peraturan-peraturan yang berlaku. Parameter mutu utama yang membedakan antara kecap kedelai manis dengan kecap kedelai asin adalah kadar proteinnya. Berdasarkan hasil analisis produk kecap kedelai manis yang beredar di Indonesia, kadar protein dari kecap kedelai manis adalah $1 \%$. Angka ini lebih kecil dibandingkan kadar protein kecap manis pada SNI 3543:1999 yaitu sebesar minimal 2,5\%. Besar kadar protein tersebut disesuaikan dengan kemampuan produsen kecap kedelai manis di Indonesia serta dengan justifikasi bahwa kecap manis tidak digunakan sebagai pangan utama pada konsumsi sehari-hari melainkan hanya merupakan bagian dari bumbu atau pencita rasa. Besar kadar gula pada kecap kedelai manis sebesar minimal $30 \%$ ditetapkan sebagai pembeda antara kecap kedelai manis dan kecap kedelai asin yang dibuat tanpa penambahan gula. Peraturan yang ditetapkan oleh BPOM untuk batasan 3-Mono Chloro Propan - 1,2 - diol (3MCPD) pada kecap kedelai tidak dimasukkan ke dalam kriteria mutu kecap kedelai manis dengan pertimbangan pada saat SNI kecap kedelai disusun belum ada lembaga yang mampu melakukan uji terhadap 3-MCPD serta mengingat sebagian besar industri kecap di Indonesia menggunakan proses fermentasi pada pembuatan kecapnya maka dianggap risiko munculnya senyawa tersebut cukup rendah. Namun mengingat risiko terhadap kesehatan yang cukup tinggi yang dapat ditimbulkan oleh senyawa 3-MCPD tersebut perlu dilakukan kaji ulang atau survei terhadap prevalensi 3-MCPD untuk produk kecap di Indonesia. Pada saat ini BBIA telah mampu melakukan analisis 3-MCPD.
\end{abstract}

Kata kunci: kecap kedelai, kecap kedelai manis, standar.

\section{Abstract}

Soy sauce is one of fermentation products that have been known since thousands years ago in various countries including Indonesia. But the sweet soy sauce is soy sauce product which is a typical product of Indonesia. The purpose of this research is to develop standardization of soy sauce products to introduce and improve the image of these products. In this study, a comparison between product testing data of some sweet soy sauce products circulating in Indonesia to some literatures was carried out, also to rules and regulations. The main quality parameter that distinguish between sweet soy sauce with salty soy sauce is protein content. Based on the analysis of sweet soy sauce products circulating in Indonesia, the protein content of sweet soy sauce is $1 \%$. This number is lower than the protein content of sweet soy sauce on the SNI 3543: 1999 which is required to be at least $2.5 \%$. The high protein content is tailored to correspond to ability of producers in Indonesia and with justification that it is only used as seasoning. More over, high sugar content in sweet soy sauce for a minimum of $30 \%$ is set to differentiate between sweet soy sauce with the salty one which is made without addition of sugar. Regulations set by the BPOM. to limit the 3-MCPD in soy sauce was not put in sweet soy sauce quality criteria with reason when SNI soy sauce was prepared there was no institution that able to test 3-MCPD and considering most of the soy sauce industry in Indonesia using fermentation process in their manufacturing process, as a result the risk is low. However, given the risks of 3-MCPD to health is high enough, it is necessary to review or survey the prevalence of 3-MCPD in soy sauce products in Indonesia. At this time BBIA has been able to perform the analysis of 3-MCPD.

Keywords: soy sauce, sweet soy sauce, standard. 


\section{PENDAHULUAN}

Kecap kedelai merupakan salah satu produk fermentasi yang digunakan sebagai produk pencita rasa khususnya di negara Asia yang merupakan produk bumbu (condiment) yang tertua di Cina selama lebih dari 3000 tahun (Muangthai dkk., 2009). Kecap kedelai dibuat menggunakan kacang kedelai yang dicampurkan dengan terigu, garam, air, dan mikroba seperti Aspergillus oryzae atau Aspergillus zozae (Impoolsup dkk., 1981). Selain melalui proses fermentasi, kecap kedelai dapat dibuat melalui proses hidrolisis protein nabati (hydrolyzed vegetable protein/ HVP). Kecap yang melalui proses HVP tersebut dibuat dengan menghidrolisis protein kedelai menjadi asam amino melalui hidrolisis asam, kemudian dicampur dengan gula, pewarna, dan bahanbahan pencitarasa lainnya sehingga memiliki citarasa menyerupai kecap kedelai yang dibuat melalui proses fermentasi (Nunomura dan Sasaki, 1986).

Kecap kedelai dapat dibagi menjadi dua tipe yaitu kecap Jepang dan kecap Cina. Kecap jepang menggunakan kedelai dan terigu dalam porsi yang sama, selanjutnya kecap Jepang dibedakan lagi menjadi shoyu koikuchi, shoyu usukuchi, dan shoyu saishikomi dimana perbedaannya terletak pada proses produksi dan karakteristik khasnya (dalam hal warna, aroma, dan viskositas). Sedangkan kecap kedelai Cina biasanya dibuat dengan sedikit sekali bahkan tanpa kandungan terigu sebagai bahan bakunya (Lioe, 2014). Di Indonesia telah dilakukan penelitian tentang pembuatan kecap dari sumber non kedelai seperti asal koro pedang (Astuti, 2012), kacang gude (Andriana, 2014) dan lamtoro gung (Rahayu, 2005) hingga ke tahap pembuatan moromi.

Salah satu ciri khas kecap kedelai khas Indonesia yang berbeda dengan negara lainnya adalah kecap kedelai manis. Berdasarkan kategori pangan (2006), kecap kedelai manis adalah produk cair yang diperoleh dari hasil fermentasi kacang kedelai (Glycine max L.) dan gula, gula merah, dengan atau tanpa proses karamelisasi dengan atau tanpa penambahan bahan lain, dengan karakteristik dasar total gula tidak kurang dari 40\%. Berdasarkan SNI 3543:2013 bagian 1, kecap kedelai manis didefinisikan sebagai produk berbentuk cair yang dibuat dari cairan hasil fermentasi kedelai atau bungkil kedelai ditambah gula dengan atau tanpa penambahan bahan pangan lain dan bahan tambahan pangan yang diizinkan. Tujuan penelitian ini adalah mengembangkan standar kecap kedelai manis yang diharapkan dapat 148 lebih memperkenalkan produk pencita rasa khas Indonesia sebagai produk unggulan berdaya saing tinggi di perdagangan global.

\section{TINJAUAN PUSTAKA}

\subsection{Pembuatan Kecap Kedelai}

Kecap kedelai dapat dibuat melalui tahapan proses yang dapat dilihat pada Gambar 1 .

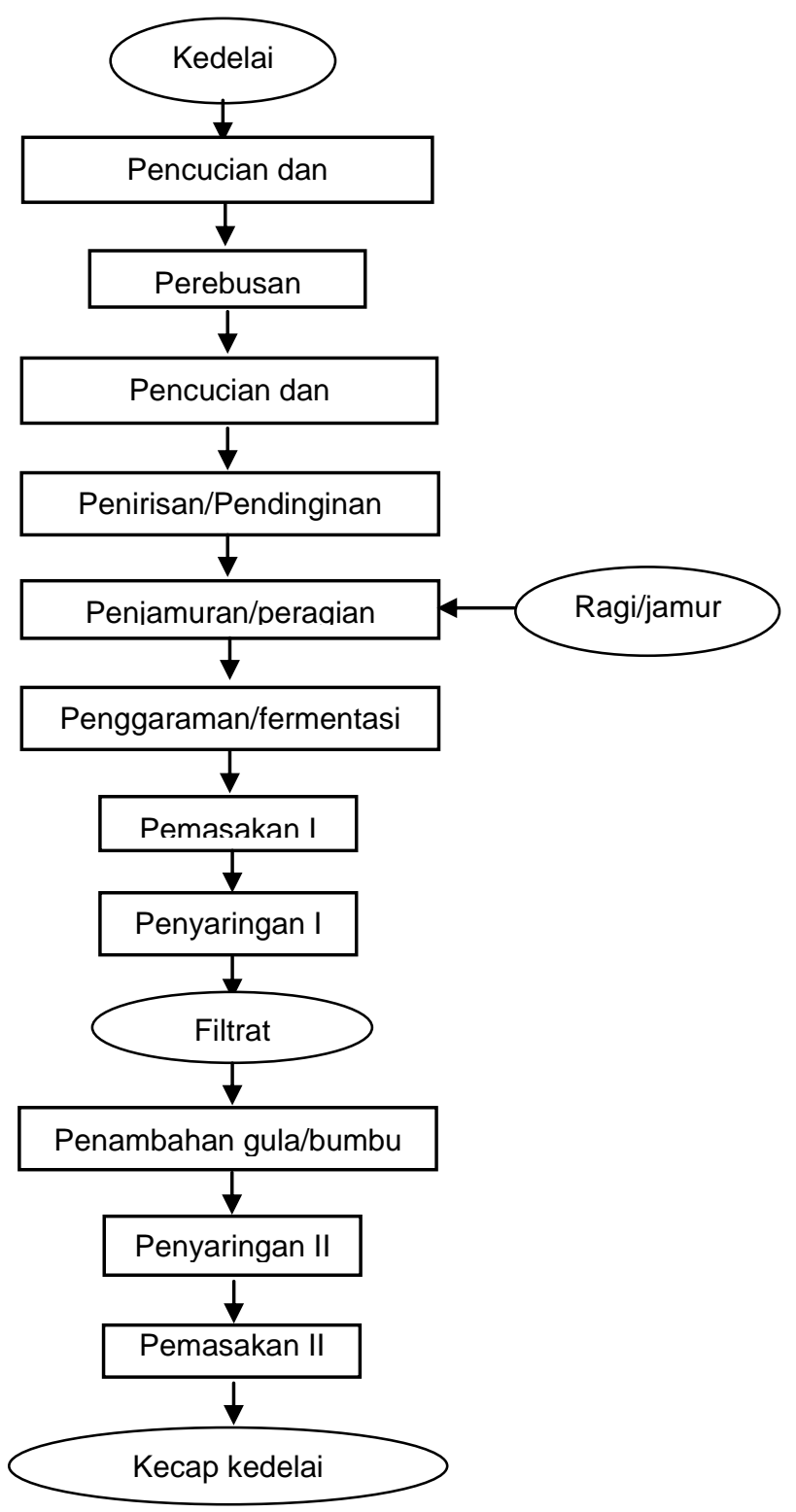

Gambar 1 Tahapan Proses Pembuatan Kecap Kedelai Manis (Maryani, 2007).

Sebagian besar proses produksi kecap termasuk dalam kategori industri pengolahan kedelai tradisional. Istilah tradisional di sini digunakan untuk menunjukkan bahwa tipe dan metode pengolahannya sudah dipraktekkan 
berabad-abad lamanya dan diwariskan secara turun-temurun kepada generasi berikutnya. Di Indonesia, umumnya kecap diproduksi dengan cara fermentasi tradisional dalam skala industri kecil dengan menggunakan peralatan yang sederhana. Seiring dengan semakin berkembangnya teknologi, saat ini telah banyak terdapat industri yang mengolah kecap dalam skala industri besar yang menggunakan peralatan yang modern (Anggono, 1993).

Proses fermentasi kecap terdiri dari 2 tahap, yaitu fermentasi padat (fermentasi koji/tempe) dan fermentasi cair (fermentasi moromi). Kapang yang digunakan dalam fermentasi padat, adalah Aspergillus sp. dan Rhizopus sp. (Rahayu dkk., 1993). Fermentasi padat memerlukan waktu selama 3-5 hari. Hasil fermentasi padat disebut koji jika menggunakan Aspergillus sp., tetapi disebut tempe jika menggunakan Rhizopus sp. Selanjutnya, koji dikeringkan, kemudian direndam dalam air garam $20-30 \%$. Proses perendaman koji dalam air garam disebut fermentasi moromi. Mikroba yang berperan dalam fermentasi moromi, adalah mikroba tahan garam seperti Hansenula sp., Zygosaccharomeces sp., dan Lactobacillus sp. (Rahayu, 1985). Fermentasi moromi memerlukan waktu selama 14-28 hari. Cairan hasil fermentasi moromi disebut moromi. Selanjutnya moromi ditambah dengan rempahrempah dan dikentalkan sehingga diperoleh kecap. Ampas dari fermentasi moromi dapat digunakan sebagai pakan ternak.

Pada fermentasi jamur (koji) maupun fermentasi dalam larutan garam (moromi) terjadi perubahan-perubahan biokimiawi oleh aktifitas enzim yang dihasilkan oleh mikroba. Pada fermentasi jamur (koji), mikroba yang dominan adalah Aspergillus soyae menghasilkan enzim protease yang dapat menghidrolisis komponenkomponen protein dalam biji kedelai. Konsentrasi garam yang optimal 17 sampai $19 \%$ berpengaruh terhadap hidrolisis protein dalam moromi dan kecepatan pembentukan asam laktat dan alkohol. Mikroba utama adalah jamur Aspergillus soyae, bakteri-bakteri asam laktat yang bersifat homofermentatif, Pseudomonas cerevisae atau P.soyae dan khamir yang toleran terhadap garam tinggi terutama Saccharomyces rouxii. Menurut Sakaguchi dalam Kasmidjo (1990), pada konsentrasi garam yang lebih tinggi $20 \%-30 \%$ P.soyae tetap tumbuh baik dan menghasilkan asam laktat tinggi sehingga dapat menurunkan $\mathrm{pH}$ sampai 4,9, bakteri tersebut berperan dalam pembentukan cita rasa dan aroma spesifik untuk kecap. Pada kondisi aerob dalam konsentrasi garam tinggi khamir yaitu S.rouxii mengubah sejumlah glukosa (50\%) menjadi gliserol, merupakan komponen penting pendukung cita rasa kecap. Menurut Suprapti (2005), gula kelapa yang ditambahkan diperlukan dalam pembuatan kecap manis, berfungsi sebagai pemanis sehingga jumlah gula kelapa yang ditambahkan dapat berpengaruh pada respon rasa kecap organik.

Faktor jenis kedelai, lama pembuatan moromi, dan jumlah gula berpengaruh terhadap hasil eksperimen yang dilakukan oleh Setiawati (2008) terhadap respon rasa, karena jenis kedelai hitam organik varietas Merapi memiliki kandungan protein kasar $36,45 \%$ sehingga cocok digunakan sebagai bahan baku pembuatan kecap karena kandungan proteinnya lebih besar dari 35\% (Suprapti, 2005), lama pembuatan moromi atau fermentasi koji dalam larutan garam dan jumlah gula kelapa juga berkaitan dengan kualitas respon rasa. Menurut Yokotsuka dalam Kasmidjo (1990), kedelai dengan kandungan protein tinggi merupakan bahan dasar yang baik untuk pembuatan kecap. Menurut Setiawati (2008), atribut kecap kedelai organik yang menjadi pertimbangan konsumen dalam membeli produk kecap antara lain: 1) cita rasa dan aroma, diperoleh dari proses pembuatan kecap secara fermentasi kedelai hitam tanpa menggunakan bahan penyedap; 2) kekentalan, tingkat kekentalan kecap manis dihasilkan dari penambahan gula kelapa tanpa penambahan bahan pengental, 3) warna coklat kehitam-hitaman pada kecap diperoleh dari gula kelapa tanpa penambahan bahan pewarna.

\subsection{Perkembangan Industri Kecap di Indonesia}

Industri kecap merupakan salah satu agroindustri yang penting untuk dikembangkan karena dapat memberikan nilai tambah komoditas kedelai yang mudah rusak, meningkatkan permintaan kedelai yang akhirnya akan meningkatkan pendapatan petani, menyerap tenaga kerja, dan menambah devisa negara melalui pemanfaatan peluang ekspor. Permasalahan yang sering dihadapai oleh industri kecap adalah semakin mahalnya harga bahan baku kedelai dan lamanya proses pembuatan kecap yang dapat berlangsung berbulan-bulan. Hal tersebut membuat sebagian pengusaha mengganti bahan baku kedelai dengan bahan-bahan lain yang lebih murah seperti air yang dicampur dengan perasa dan pewarna kecap. Akibatnya, kualitas kecap cenderung menurun atau encer sedangkan kuantitas produksinya meningkat. Sementara itu, perkembangan industri kecap di Indonesia, tumbuh seiring dengan peningkatan konsumsi kecap dalam masyarakat (Maryani, 2007). 
Berdasarkan data dari Direktori Perusahaan Industri Kementerian Perindustrian, terdapat 50 industri kecap di Indonesia yang tersebar di berbagai daerah. Gambar 2 menunjukkan sebaran industri kecap di Indonesia dengan jumlah industri kecap terbanyak di Jawa Barat sejumlah 22 industri.

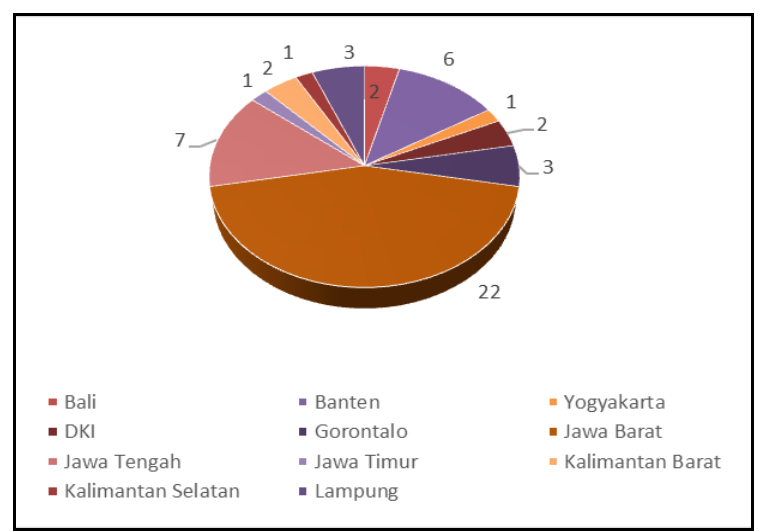

Gambar 2 Direktori Industri Kecap Kedelai di Indonesia (Kemenperin, 2015)

Bila dilihat dari wujud kedelai yang diekspor selama tahun 2004-2008 adalah sebagian besar atau lebih dari $80 \%$ dalam bentuk kedelai olahan, dimana berdasarkan volume ekspor 2008 sebesar $88,63 \%$ ( 7,99 ribu ton) ekspor Indonesia dalam bentuk olahan dengan kontribusi nilai ekspor sebesar 82,97\% (US\$ 6,85 juta). Bila dilihat lebih jauh berdasarkan kode HS (Harmonized Sistem) ekspor kedelai tahun 2008 sebagian besar dalam wujud kecap manis (HS 2103100010) sebesar $80,67 \%$ dari total nilai ekspor kedelai atau US\$ 6,66 juta, 17,03\% kedelai segar

Tabel 1 Syarat mutu kecap kedelai manis (SNI 3543: 2013 bagian 1).

\begin{tabular}{clcc}
\hline No. & \multicolumn{1}{c}{ Kriteria Uji } & Satuan & Persyaratan \\
\hline 1 & Keadaan & & \\
1.1 & Bau & - & Normal, khas \\
1.2 & Rasa & - & Normal, khas \\
2 & Kadar protein $(\mathrm{Nx6,25)}$ & $\%(\mathrm{~b} / \mathrm{b})$ & $\mathrm{min} .1,0$ \\
3 & Kadar gula (dihitung sebagai sakarosa) & $\%(\mathrm{~b} / \mathrm{b})$ & $\mathrm{min} .30$ \\
4 & pH & - & $3,5-6,0$ \\
5 & Cemaran logam & & \\
5.1 & Timbal $(\mathrm{Pb})$ & $\mathrm{mg} / \mathrm{kg}$ & maks. 1,0 \\
5.2 & Kadmium (Cd) & $\mathrm{mg} / \mathrm{kg}$ & maks. 0,2 \\
5.3 & Timah $(\mathrm{Sn})$ & $\mathrm{mg} / \mathrm{kg}$ & maks. 40,0 \\
5.4 & Merkuri $(\mathrm{Hg})$ & $\mathrm{mg} / \mathrm{kg}$ & maks. 0,05 \\
6 & Cemaran arsen (As) & $\mathrm{mg} / \mathrm{kg}$ & maks. 0,5 \\
7 & Cemaran mikroba & & \\
\hline
\end{tabular}

lainnya (HS 1201009000) atau US $\$ 1,41$ juta dan $2,07 \%$ tepung kedele lainnya (HS 1208900000 ) atau US\$ 171 ribu. Bila ditelusuri lebih jauh negara tujuan ekspor utama kedelai segar lainnya (HS 1201009000) tahun 2008 sebesar $86,17 \%$ ke Jepang, 9,60\% ke Korea dan 2,01\% ke Singapore (Gambar 4.7), sementara negara tujuan ekspor kecap (HS 2103100000) terbesar adalah ke negara Australia sebesar $26,49 \%$, $13,87 \%$ ekspor ke Saudi Arabia, $12,59 \%$ ekspor ke Belanda, $9,80 \%$ ke USA dan $6,36 \%$ ke Malaysia (Pusdatin Pertanian, 2009).

\section{METODE PENELITIAN}

Metode penelitian yang digunakan dalam penelitian ini adalah dengan melakukan suatu telaah kualitatif dengan pendekatan studi pustaka serta mengkaji hasil analisis produk kecap kedelai di Balai Besar Industri Agro (BBIA), membandingkan dengan Standar Internasional yang berlaku untuk produk sejenis, serta mengacu pada peraturan-peraturan yang berlaku dalam rangka penyusunan SNI kecap kedelai manis. Hasil telaah pustaka dan hasil analisis pengujian kecap kedelai selanjutnya dianalisis secara deskriptif dan hasilnya diinterpretasikan sesuai dengan tujuan studi.

\section{PEMBAHASAN DAN ANALISA}

Standar Nasional Indonesia untuk kecap kedelai manis yang terdapat pada SNI 3543: 2013 dapat dilihat pada Tabel 1. 


\begin{tabular}{clcc}
\hline No. & \multicolumn{1}{c}{ Kriteria Uji } & Satuan & Persyaratan \\
\hline 7.1 & Bakteri coliform & APM $/ g$ & $<3$ \\
7.2 & Kapang & koloni $/ \mathrm{g}$ & maks. 50 \\
8 & Aflatoksin* & \\
8.1 & B $_{1}$ & $\mu \mathrm{gg} / \mathrm{kg}$ & maks. 15 \\
8.2 & Total aflatoksin & $\mu \mathrm{gg} / \mathrm{kg}$ & maks. 20 \\
\multicolumn{2}{l}{ Catatan: * hanya untuk cairan hasil fermentasi kedelai } & \\
\hline
\end{tabular}

Secara garis besar untuk kriteria mutu yang terdapat pada kecap kedelai manis terbagi menjadi 3 kelompok besar yaitu kriteria mutu secara organoleptik, mutu secara kimia, dan mutu secara mikrobiologis. Untuk kriteria mutu kecap kedelai manis meliputi kadar protein, kadar gula, dan $\mathrm{pH}$. Kandungan protein merupakan parameter kualitas kecap manis (Direktorat Gizi Depkes RI, 1996). Pada SNI kecap kedelai sebelumnya (SNI 3543 - 1999) tertulis bahwa kadar protein kecap kedelai manis adalah minimal 2,5\% dan minimal 4\% untuk kecap kedelai asin, dengan pertimbangan bahwa kecap kedelai manis sudah ditambahkan dengan gula dan bumbu-bumbu lainnya. Hasil penelitian Purwoko dan Handajani (2007) yang menguji kadar protein dari kecap yang difermentasi dengan Rhyzopus oryzae dan $R$. oligosporus menunjukkan bahwa kecap manis tanpa fermentasi moromi mampu menghasilkan kandungan protein terlarut dan protein total lebih tinggi daripada kecap manis dengan fermentasi moromi. Kecap manis hasil fermentasi $R$. oligosporus mengandung kadar protein terlarut dan protein total lebih tinggi daripada kecap manis hasil fermentasi $R$. oryzae. Kandungan protein terlarut kecap manis hasil fermentasi $R$. oligosporus tanpa fermentasi moromi adalah $8,2 \%$, sedangkan kandungan protein terlarut kecap manis hasil fermentasi $R$. oryzae tanpa fermentasi moromi adalah $4,1 \%$.

Hasil analisis kadar protein dari berbagai produsen kecap manis di Indonesia yang dilakukan oleh BBIA dapat dilihat pada Tabel 2. Produk kecap komersial yang dianalisis mencakup perusahaan kecap dalam skala besar dan skala kecil di Indonesia.

Tabel 2 Hasil analisis kadar protein kecap kedelai manis dari produsen kecap.

\begin{tabular}{|c|c|c|c|}
\hline $\begin{array}{l}\text { Contoh Kecap } \\
\text { Kedelai Manis }\end{array}$ & $\begin{array}{c}\text { Kadar Protein } \\
\text { (N x 6,25) dalam \% }\end{array}$ & $\begin{array}{l}\text { Contoh Kecap } \\
\text { Kedelai Manis }\end{array}$ & $\begin{array}{c}\text { Kadar Protein } \\
(\mathrm{N} \times 6,25) \text { dalam \% }\end{array}$ \\
\hline Kecap Manis 1 & 1,60 & Kecap manis 16 & 1,23 \\
\hline Kecap Manis 2 & 1,27 & Kecap manis 17 & 1,17 \\
\hline Kecap Manis 3 & 1,56 & Kecap manis 18 & 1,28 \\
\hline Kecap manis 4 & 1,49 & Kecap manis 19 & 1,27 \\
\hline Kecap manis 5 & 1,25 & Kecap manis 20 & 1,46 \\
\hline Kecap manis 6 & 1,20 & Kecap manis 21 & 1,09 \\
\hline Kecap manis 7 & 1,47 & Kecap manis 22 & 1,38 \\
\hline Kecap manis 8 & 1,83 & Kecap manis 23 & 1,21 \\
\hline Kecap manis 9 & 1,00 & Kecap manis 24 & 1,27 \\
\hline Kecap manis 10 & 1,02 & Kecap manis 25 & 1,69 \\
\hline Kecap manis 11 & 1,47 & Kecap manis 26 & 1,32 \\
\hline Kecap manis 12 & 1,26 & Kecap manis 27 & 1,28 \\
\hline Kecap manis 13 & 1,24 & Kecap manis 28 & 1,21 \\
\hline Kecap manis 14 & 1,41 & Kecap manis 29 & 0,68 \\
\hline Kecap manis 15 & 1,19 & Kecap manis 30 & 1,26 \\
\hline \multicolumn{3}{|c|}{ Rata-rata kadar protein } & 1,30 \\
\hline
\end{tabular}


Berdasarkan hasil analisis kadar protein kecap kedelai dapat dilihat bahwa rata-rata kadar protein dari 30 produk kecap kedelai manis di Indonesia adalah 1,30\% dengan kadar protein tertinggi adalah $1,83 \%$ dan kadar protein terendah sebesar $0,68 \%$. Hasil kadar protein ini berbeda dengan hasil penelitian yang dilakukan oleh Purwoko dan Handajani (2007) dikarenakan pada penelitian tersebut pembuatan kecap dilakukan pada skala kecil (laboratorium), sedangkan pada kenyataan di lapangan banyak faktor yang mempengaruhi pertumbuhan dari ragi yang terlibat pada proses fermentasi yang dapat mempengaruhi kadar protein terlarut dari produk kecap kedelai manis. Hal ini yang menjadi justifikasi penetapan kadar protein pada kecap kedelai manis yaitu minimum $1 \%$. Selain itu bila dilihat dalam pertimbangan kesehatan konsumen, kecap hanya digunakan sebagai pencita rasa produk, bukan sebagai bahan pangan utama. Dalam hal penetapan angka protein, standar yang ditetapkan harus tetap melihat kenyataan yang ada pada lapangan, jangan sampai dengan penetapan yang terlalu tinggi berdampak pada jatuhnya industri kecap kedelai manis di Indonesia. Mengingat kecap kedelai manis juga merupakan produk pencita rasa khas Indonesia.

Kadar gula yang terkandung pada kecap kedelai manis ditetapkan minimal sebesar $30 \%$ untuk mengelompokkan kecap kedelai sebagai kecap kedelai manis. Tabel 3 menunjukkan hasil uji kadar gula dari beberapa produsen kecap di Indonesia yang dianalisis di BBIA.

Tabel 3 Hasil analisis kadar gula kecap kedelai manis.

\begin{tabular}{lc}
\hline $\begin{array}{c}\text { Contoh Kecap Kedelai } \\
\text { Manis }\end{array}$ & $\begin{array}{c}\text { Kadar Gula } \\
\text { (Sebagai Sakarosa) } \\
\text { dalam \% }\end{array}$ \\
\hline Kecap kedelai manis 1 & 63,7 \\
Kecap kedelai manis 2 & 64 \\
Kecap kedelai manis 3 & 30,2 \\
Kecap kedelai manis 4 & 51,7 \\
Kecap kedelai manis 5 & 32,5 \\
Kecap kedelai manis 6 & 67,5 \\
Kecap kedelai manis 7 & 67,4 \\
Kecap kedelai manis 8 & 64,9 \\
Kecap kedelai manis 9 & 64,7 \\
Kecap kedelai manis 10 & 65,1 \\
Kecap kedelai manis 11 & 64,2 \\
Kecap kedelai manis 12 & 65,6 \\
\hline
\end{tabular}

\begin{tabular}{cc}
\hline $\begin{array}{c}\text { Contoh Kecap Kedelai } \\
\text { Manis }\end{array}$ & $\begin{array}{c}\text { Kadar Gula } \\
\text { (Sebagai Sakarosa) } \\
\text { dalam \% }\end{array}$ \\
\hline Kecap kedelai manis 13 & 65,8 \\
Kecap kedelai manis 14 & 65,6 \\
Kecap kedelai manis 15 & 65,7 \\
Kecap kedelai manis 16 & 66,4 \\
Kecap kedelai manis 17 & 66,4 \\
Kecap kedelai manis 18 & 66,5 \\
Kecap kedelai manis 19 & 66,3 \\
Kecap kedelai manis 20 & 66,3 \\
Kecap kedelai manis 21 & 66,2 \\
Kecap kedelai manis 22 & 22,2 \\
Kecap kedelai manis 23 & 66,9 \\
Rata-rata kadar gula & $\mathbf{6 0 , 3 8}$ \\
\hline
\end{tabular}

Berdasarkan hasil analisis produk kecap kedelai dapat dilihat bahwa rata-rata kadar gula kecap kedelai manis adalah $60,38 \%$. Kadar gula pada kecap kedelai menjadi pembeda antara kecap kedelai manis dan kecap kedelai asin. Selain itu penambahan gula dan bumbu-bumbu pada sari fermentasi kedelai merupakan salah satu kekhasan kecap kedelai manis dibandingkan dengan produk kecap kedelai lainnya. Pada SNI 3543:1999 ditetapkan bahwa kadar gula minimal untuk kecap kedelai manis adalah $40 \%$, namun mengingat pada contoh uji kecap kedelai terdapat kecap kedelai yang kadar gulanya kurang dari $40 \%$ maka untuk mengakomodir semua contoh kecap kedelai manis di Indonesia ditetapkan bahwa kadar gula kecap kedelai manis minimal $30 \%$. Kadar gula pada kecap kedelai manis lebih terkait pada kualitas

organoleptik dari kecap kedelai manis, sehingga besar kadar gula pada kecap kedelai manis mempengaruhi penerimaan konsumen terhadap kecap kedelai manis.

Keasaman kecap kedelai yang ditunjukkan dengan $\mathrm{pH}$ menunjukkan kisaran dari suatu produk hasil fermentasi kedelai tersebut, dimana seperti yang telah dijelaskan sebelumnya bahwa adanya keterlibatan Bakteri Asam Laktat (BAL) pada proses fermentasi kecap yang menjadikan $\mathrm{pH}$ dari produk kecap kedelai manis berada pada kisaran 3,5-6.

Untuk batasan cemaran mikrobiologis komoditas kecap kedelai manis mengikuti regulasi yang terdapat pada Badan Pengawas Obat dan Makanan. Berdasarkan Peraturan Kepala BPOM Republik Indonesia No. HK. 00.06.1.52.4011 Tahun 2009 tentang Penetapan 
Batas Maksimum Cemaran Mikroba dan Kimia dalam Makanan, batasan cemaran mikroba untuk kecap kedelai manis adalah maksimum < $3 \mathrm{APM} / \mathrm{ml}$ untuk koliform dan kapang maksimum $50 \mathrm{koloni} / \mathrm{g}$. Koliform merupakan salah satu bakteri yang merupakan indikator sanitasi pada pangan. Bakteri indikator sanitasi adalah bakteri yang keberadaannya dalam pangan menunjukkan bahwa air atau makanan tersebut pernah tercemar oleh kotoran manusia dikarenakan bakteri-bakteri indikator sanitasi tersebut pada umumnya adalah bakteri yang lazim terdapat dan hidup pada usus manusia. Jadi adanya bakteri tersebut pada air atau makanan menunjukkan bahwa dalam satu atau lebih tahap pengolahan air atau makanan tersebut pernah mengalami kontak dengan kotoran yang berasal dari usus manusia dan oleh karenanya mungkin mengandung bakteri patogen lainnya yang berbahaya (DewantiHariyadi, 2012). Meskipun proses pembuatan kecap kedelai menggunakan kapang, namun cemaran kapang tetap dibatasi pada proses pembuatan kecap kedelai. Proses pemasakan dapat mereduksi jumlah kapang yang terdapat pada cairan fermentasi kecap tersebut. Pembatasan jumlah kapang tersebut sangat penting mengingat bahwa kapang berpotensi untuk dapat menghasilkan aflatoksin yang membahayakan bagi tubuh.

Batas maksimum cemaran total aflatoksin pada kecap kedelai manis adalah $20 \mathrm{ppb}$ dan batas maksimum aflatoksin $B_{1}$ adalah $15 \mathrm{ppb}$. Hal ini telah sesuai dengan Peraturan BPOM No. HK. 00.06.1.52.4011. Aflatoksin dapat terbentuk sebagai hasil metabolit dari kapang penghasil aflatoksin serta kontaminasi kapang yang mungkin dapat berasal dari bahan baku dan gudang penyimpanan, bila tidak disimpan dengan baik. Karena itu dalam pemilihan kapang atau jamur yang digunakan pada pembuatan kecap adalah jamur yang bukan pembentuk aflatoksin perlu dijadikan bahan pertimbangan dalam produksi kecap kedelai. Maing dkk., (1973) melaporkan bahwa tidak ada aflatoksin yang terdeteksi pada fermentasi kecap dengan A.oryzae dan Lactobacillus delbrueckii. Produksi asam dari $L$. delbrueckii sebagai bakteri asam laktat (BAL) dapat mengkatalis konversi aflatoksin B menjadi derivatnya yang bersifat non toksin. Menurut Noda dkk., (1980) pada tahapan fermentasi menggunakan air garam pada pembuatan kecap adalah terjadi keterlibatan khamir osmofilik dan BAL. Selama proses fermentasi yang berlangsung selama 6 sampai dengan 8 bulan dalam kondisi suhu yang terkontrol, enzim yang terdapat pada ragi menghidrolisis hampir sebagian besar protein menjadi asam amino dan peptida berberat molekul rendah. Sebagian besar pati dikonversi menjadi gula sederhana. Pada tahap akhir fermentasi kecap kedelai terjadi pembentukan galur-galur khamir osmofilik seperti Torulopsis versatilis dan Torulopsis etchelsii yang memproduksi komponen fenolik yang berperan dalam pembentukan aroma spesifik pada shoyu. Kun-young dkk., (1988) melaporkan bahwa selama proses fermentasi berlangsung, produksi aflatoksin lebih banyak pada kondisi yang menggunakan kultur campuran. Produksi aflatoksin G1 sangat mudah terstimulasi dan dapat terdegradasi dengan cepat, sedangkan aflatoksin B1 sangat lambat pembentukannya. Jumlah total aflatoksin yang terdapat pada proses fermentasi yang disimulasikan dengan $A$. parasiticus menunjukkan bahwa selama proses pematangan meju (makanan fermentasi kedelai asal Korea) terjadi degradasi aflatoksin secara signifikan, serta terjadi peningkatan degradasi aflatoksin pada fermentasi yang melibatkan arang aktif pada campuran fermentasi. Hal ini dapat menunjukkan bahwa selama proses fermentasi kecap kedelai dilangsungkan secara terkendali, dalam artian suhu proses yang terkendali serta mencegah adanya kontaminasi silang dari bahan baku atau lingkungan proses produksi, maka jumlah aflatoksin yang terdapat pada kecap kedelai harus memenuhi persyaratan yang telah ditetapkan oleh BPOM.

Senyawa kimia yang menjadi perhatian pada produk kecap kedelai adalah senyawa kloropropanol yaitu 3-Mono Chloro Propan - 1,2 - diol (3-MCPD) dan 1,3-dikloropropan-2-ol (1,3DCP) yang bersifat karsinogenik. Pada Peraturan BPOM No. HK. 00.06.1.52.4011 disebutkan bahwa batasan cemaran 1,3-diol untuk kecap adalah maksimum $5 \mathrm{ppb}$ dan batasan 3-MCPD adalah maksimum $20 \mathrm{ppb}$ dengan kategori untuk makanan yang mengandung protein nabati yang terhidrolisis dengan asam. Berdasarkan SNI 7501:2009 (tentang Batas Maksimum Cemaran Kimia (benzo [a] piren, dioksin (2,3,7,8-TCDD), 1,3dikloropropan-2-ol (1,3-DCP), dan 3monokloropropan-1,2-diol dalam pangan) hal-hal yang dapat menjadi sumber cemaran kloropropanol pada kecap yaitu penambahan acid-HVP, hidrolisa asam dari sebagian atau seluruh kacang kedelai/gandum, serta proses pemanggangan gandum. 3-MCPD dapat ditemukan sebagai kontaminan dalam kopolimer ephichlorhydrin/amine yang digunakan sebagai bahan flokulan atau koagulan dalam pengolahan air. Oleh karena itu, 3-MCPD juga dapat ditemukan pada air minum. Tahapan proses berikut diduga sebagai sumber pembentukan 3- 
MCPD yaitu: sudah ada secara alamiah dalam bahan baku; penyimpanan bahan baku, penggunaan air berklorinasi pada saat pencucian; perlakuan proses komersial termasuk baking, penguapan, fermentasi, malting, pasteurisasi, pemanggangan, pengasapan, spray drying, sterilisasi, dan UHT; migrasi dari bahan yang kontak langsung dengan makanan; dan penyimpanan produk jadi. Pada SNI 3543: 2013 (kecap kedelai), senyawa 3-MCPD tidak dimasukkan ke dalam batasan cemaran kimia pada kriteria mutu. Hal ini dengan mempertimbangkan bahwa sebagian besar industri kecap merupakan industri kecil dan menengah dan sebagian besar proses pembuatan kecapnya dilakukan melalui fermentasi (bukan dengan hidrolisis asam), dan pada saat rapat penyusunan SNI kecap kedelai belum ada lembaga yang mampu melakukan analisis terhadap 3-MCPD. Selain itu bila melihat dari prevalensi munculnya 3-MCPD lebih banyak pada produk kecap yang merupakan hasil hidrolisis asam. Wei-Chih Heng dkk. (2004) telah melakukan survey kandungan 3-MCPD pada 240 produk kecap pada tahun 2002 di Taiwan (188 produk lokal Taiwan dan 26 produk impornya) dan melaporkan bahwa 3-MCPD tidak terdeteksi pada 87 contoh kecap lokalnya dan 23 contoh kecap impornya. 91 contoh dari kecap lokal megandung 3-MCPD dengan konsentrasi pada kisaran konsentrasi 0,01 ppm hingga 1 ppm, dimana 10 contoh kecap lokalnya mengandung 3-MCPD dengan konsentrasi lebih dari 1 ppm. Namun hasil survei tahun 2002 tersebut menunjukkan adanya penurunan jumlah sampel yang mengandung 3-MCPD dibandingkan dengan survei sebelumnya pada tahun 2000. MacArthur dkk. (2000) juga melakukan survei kandungan 3-MCPD pada kecap dan produk-produk yang serupa di Inggris. Dilaporkan bahwa produk kecap yang ada di sebagian negara-negara Eropa mengandung 3MCPD dalam jumlah yang besar (hingga 124 $\mathrm{mg} / \mathrm{kg}$ ). Hal yang sama perlu dilakukan juga di Indonesia, mengingat senyawa 3-MCPD ini bersifat sangat karsinogenik. Pada saat ini BBIA telah mampu melakukan analisis 3-MCPD, sehingga dapat membantu dalam melakukan kajian risiko 3-MCPD pada produk-produk berisiko di Indonesia, khususnya kecap.

\section{KESIMPULAN}

Kecap kedelai manis merupakan produk pencitarasa khas Indonesia yang umumnya dibuat melalui proses fermentasi tradisional. Kandungan protein merupakan parameter kualitas kecap manis, dimana pada SNI 154
3543:2013 kadar protein kecap kedelai manis adalah 1\%. Besar kadar protein tersebut disesuaikan dengan kemampuan produsen kecap kedelai manis di Indonesia serta dengan justifikasi bahwa kecap manis tidak digunakan sebagai pangan utama pada konsumsi seharihari melainkan hanya merupakan bagian dari bumbu atau pencita rasa. Besar kadar gula pada kecap kedelai manis sebesar minimal 30\% ditetapkan sebagai pembeda antara kecap kedelai manis dan kecap kedelai asin yang dibuat tanpa penambahan gula. Kecap kedelai manis yang ditambahkan dengan gula dan rempah-rempah pada proses pembuatannya juga merupakan pencita rasa khas Indonesia.

Batasan cemaran logam dan mikroba pada kecap kedelai manis menyesuaikan dengan Peraturan yang ditetapkan oleh BPOM, namun untuk batasan 3-MCPD pada kecap kedelai tidak dimasukkan ke dalam kriteria mutu kecap kedelai manis dengan pertimbangan pada saat SNI kecap kedelai disusun belum ada lembaga yang mampu melakukan uji terhadap 3MCPD serta mengingat sebagian besar industri kecap di Indonesia menggunakan proses fermentasi pada pembuatan kecapnya maka dianggap risiko munculnya senyawa tersebut cukup rendah. Namun mengingat risiko terhadap kesehatan yang cukup tinggi yang dapat ditimbulkan oleh senyawa 3-MCPD tersebut perlu dilakukan kaji ulang atau survey terhadap prevalensi 3-MCPD untuk produk kecap di Indonesia. Pada saat ini BBIA telah mampu melakukan analisis 3-MCPD.

\section{UCAPAN TERIMA KASIH}

Ucapan terima kasih penulis ucapkan pada Direktorat Industri Makanan, Hasil Laut, dan Perikanan, Direktorat Industri Agro, Kementerian Perindustrian atas dana dalam penyusunan SNI Kecap Kedelai pada tahun 2011.

\section{DAFTAR PUSTAKA}

Andriana, D. (2014). Pengaruh substitusi Kacang Gude (Cajanus cajan) Terhadap Kadar Protein dan Daya Terima Kecap Kedelai. Unnes Journal of Public Health 3 (3) : 1-8

Anggono, Y. (1993). Analisis Agroindustri Kecap.Skripsi. Fakultas Pertanian. Institut Pertanian Bogor. Bogor.

Astuti, B.B. (2012). Karakteristik Moromi yang Dihasilkan dari Fermentasi Moromi Kecap Koro Pedang (Canavalia ensiformis L.) Pada Kondisi Fermentasi yang Berbeda. 
Tesis. Universitas Gajah Mada. Yogyakarta.

Badan Standardisasi Nasional. (1999). Standar Nasional Indonesia (SNI) 3543:1999. Kecap kedelai. Jakarta.

(2009). Standar Nasional Indonesia (SNI) 7501:2009. Batas Maksimum Cemaran Kimia (benzo[a] piren, dioksin (2,3,7,8$T C D D)$, 1,3-dikloropropan-2-ol (1,3-DCP), dan 3-monokloropropan-1,2-diol dalam Pangan. Jakarta.

(2013). Standar Nasional Indonesia (SNI) 3543: 2013. Kecap Kedelai bagian 1: Manis. Jakarta.

Badan Pengawas Obat dan Makanan. (2006). Surat Keputusan Kepala Badan Pengawas Obat dan Makanan Republik Indonesia No. HK.00.05.52.4040 Tahun 2006 tentang Kategori Pangan. Jakarta.

(2011). Peraturan Kepala Badan Pengawas Obat dan Makanan Republik Indonesia No. HK. 00.06.1.52.4011 Tahun 2009 tentang Penetapan Batas Maksimum Cemaran Mikroba dan Kimia dalam Makanan.

Dewanti-Hariyadi, Ratih. (2011). Di dalam Wiarsini, D.A. 2011. Bakteri Indikator Sanitasi dan Keamanan Air Minum. Diakses 6 April 2015 dari http://www.scribd.com/doc/65604944/Bakt eri-Indikator-Sanitasi-Dan-Keamanan-AirMinum\#scribd.

Direktorat Gizi Depkes RI. (1996) Daftar komposisi bahan makanan. Bharata. Jakarta.

Impoolsup, A., A. Bhumiratana, and T.W. Flegel. (1981). Isolation of alkaline and neutral proteases from Aspergillus flavus var. columnaris, a soy sauce koji mold. Applied and Environmental Microbiology 42: 619 628.

Kasmidjo, R. B. (1990). Tempe Mikrobiologi dan Biokimia Pengolahan Serta Pemanfaatannya. PAU Pangan dan Gizi UGM. Yogyakarta.

Kementerian Perindustrian RI. 2015. Direktori Perusahaan Industri Kementerian Perindustrian. Diakses 1 April 2015 dari www.kemenperin.go.id.

Kun-young, Park, L.Kyu-Bok, L.B. Bullerman. (1988). Aflatoxin Production by Aspergillus paraciticus and Its Stability During the Manufacture of Korean Soy Paste (Doenjang) and Soy Sauce (Kanjang) by Traditional Method. Journal of Food Protection 12: 916 - 981.
MacArthur, R., C. Crews, A. Davies, P.Brereton, P. Hough, D. Harvey. (2000). 3Monochloropropane-1,2-diol (3-mCPD) in Soy Sauces and Similar Products Available from Retail Outlets in the UK. Journal Food Additives and Contaminants Vol. 7: $903-906$.

Maing, II-Young, I.J.C. Ayres, and P.E. Koehler. (1973). Persistence of Aflatoxin During the Fermentation of Soy Sauce. Applied and Environmental Microbiology 25: 1015 1017.

Maryani, Rina. (2007). Analisis Permintaan dan Penawaran Industri Kecap di Indonesia. SKRIPSI. Departemen IImu Ekonomi. Fakultas Ekonomi dan Manajemen. Institut Pertanian Bogor. Bogor.

Muangthai, P, U. P. Suwunna, and W. Patumpai. (2009). Development Of Healthy Soy Sauce From Pigeon Pea And Soybean. Asian Journal of Food and Agro Industry Vol.2: $291-301$.

Noda, F., K. Hayashi, and T. Mizunuma. (1980). Antagonism Between Osmophilic Lactic Acid Bacteria and Yeast in Brine Fermentation of Soy Sauce. Applied and Environmental Microbiology 40: 452 - 457.

Nunomura,N., M. Sasaki. (1986). Legume-Based Fermented Foods. CRC Press, Inc.. Boca Raton, FL.

Purwoko, Tj. dan N.S. Handajani. (2007). Kandungan Protein Kecap Manis Tanpa Fermentasi Moromi Hasil Fermentasi Rhyzopus oryzae dan $R$. oligosporus. Biodiversitas 8: 223 - 227.

Pusat Data dan Informasi Pertanian. (2009). Kinerja Perdagangan Kedelai. Kinerja Perdagangan Komoditas Pertanian .Volume 1 No. 1: 13 - 33.

Rahayu, E.S. (1985). Hidrolisis Protein Kedelai oleh Aspergillus oryzae, A. soyae, dan Rhizopus oligosporus. Tesis. Fakultas Pascasarjana UGM, Yogyakarta.

Rahayu, E.S., R. Indrati, T. Utami, E. Harmayani, dan M.N. Cahyanto. (1993). Bahan Pangan Hasil Fermentasi. PAU Pangan \& Gizi, Yogyakarta.

Rahayu, A., Suranto, P. Tjahjadi. (2005). Analisis Karbohidrat, Protein, dan Lemak pada Pembuatan Kecap Lamtoro Gung (Leucaena leucocephala) Terfermentasi Aspergillus oryzae. Bioteknologi Vol 2: 14 -20 .

Setiawati, B.B. (2008). Penentuan Komponen Kualitas dan Bahan Baku Optimal 8 - 19 Produk Kecap Organik Berbasis Off Line 
Quality Control. Jurnal-jurnal IImu Pertanian 4: 8 -19.

Suprapti, M.L. (2005). Kecap Tradisional. Penerbit Kanisius. Yogyakarta.

Wei-Chih Heng, Hui-chang chen, Yi-Ping Lin, Hui-Fang Lee, Pi-Chiou chang, and Shin-
Shu Chou. (2004). Survey on 3Monochloro-1,2-propandiol (3-MCPD) Contents of Soy Sauce Products during Fiscal Year 2002 in Taiwan. Journal of Food and Drug Analysis 12: 3356 - 341. 